\title{
СТАРООБРЯДЧЕСТВО В СОВРЕМЕННОЙ ПОЛИТИЧЕСКОЙ КУЛЬТУРЕ: ЕВРОПЕЙСКИЕ ЦЕННОСТИ
}

\begin{abstract}
Аннотация. В статье рассматриваются пути адаптации старообрядчества в современной российской политической культуре на основе анализа официальных старообрядческих документов, материалов конфессиональной прессы, а так же полевых исследований автора. Делаются выводы о причинах возвращения старообрядчества в общественно-политический дискурс современных государственно-конфессиональных отношений, даются прогнозы относительно влияния старообрядчества на современную российскую политическую культуру в направлении её демократизации.
\end{abstract}

Ключевые слова: старообрядчество, русский мир, традциионность, идентичность, политика, культура.

Старообрядчество как общественно-религиозное явление, вышедшее из недр раскола православной церкви в России, сразу приобрело не только российский, но и европейский характер. Гонения, обрушивавшиеся на раскольников вплоть до Манифеста 1905 г., вынуждали их бежать за пределы Российской империи, размещаться на территории Речи Посполитой и других государств, где государственно-конфессиональные отношения были более мягкими. И сегодня большие старообрядческие общины существуют на Украине, в Беларуси, странах Балтии, Восточной Европе, Северной и Южной Америке, Австралии. Старообрядцы, являясь гражданами этих стран, участвуют во всех демократических процедурах, сочетая религиозный традиционализм с практикой жизни в условиях демократии. В современной российской политической культуре и государственно-конфессиональных отношениях, старообрядчество занимает особую субкультурную нишу. Имея богатую историю, старообрядческое сообщество самоопределяется в современности, основываясь на традиционализме, отвергающем «адаптацию религиозного компонента к державным интересам», получившем в России, по утверждению М.Ю. Смирнова «гипертрофированное воплощение, став стержнем авторитарно-этатистского уклада, доминирующего в стране на протяжении всей её истории» ${ }^{1}$. Отличительные черты старообрядчества: культивация общинности, эсхатологизм, этический максимализм, традиционализм, книжность, нравственное обоснование труда и предпринимательской деятельности и др. Все направления современного старообрядчества ищут пути синтеза современности

(C) Шиманская Ольга Константиновна - кандидат философских наук, доцент, старший научный сотрудник Центра по изучению проблем религии и обшества Отдела социальных и политических исследований Института Европы РАН. Адрес: 125009, Россия, Москва, ул. Моховая, д. 11, стр. 3.E-mail: shimansk@mail.ru.

DOI: http://dx.doi.org/10.15211/vestnikieran32019117124

${ }^{1}$ Смирнов М.Ю. Религия и религиоведение в России. СПб., 2013. С. 27. 
с особенностями старообрядческой культуры, ведя дискуссии о формах традиционализма, сути мирского призвания верующих и церковных институций.

Традиционализм - принципиальная основа религиозных, социальных, культурных воззрений старообрядцев. Они сохранили традиционный этикет, костюм, национальную кухню, уклад семейной и хозяйственной жизни, сложный комплекс мифоритуальных обрядов и верований, традиционную русскую культуру как систему. Артикулирует это культура старообрядцев-иммигрантов, живущих в инокультурной среде, но сохранивших язык предков и национально-культурное своеобразие. Как пишет А.Б. Островский: «Стремление к точному соблюдению обрядовых норм, присущее и в настоящее время многим старообрядческим группам, наряду с убеждением в религиозной значимости этих норм, выражает также этноконфессиональную идентичность, служит своего рода камертоном исторической памяти» ${ }^{1}$. Общинный уклад жизни культивирует установку на соборное единство. Опора личности на общину и учёт интересов общины в индивидуальной деятельности определили специфику и успех старообрядческого предпринимательства. Этико-религиозный комплекс старообрядчества привёл к возникновению многих черт, характерных для модернизирующегося общества. Если на Западе протестантизм стал религией формирующейся буржуазии, то в России XIX в. старообрядчество - осуществило первоначальное накопление капитала. Староверы нуждались в прочной экономической базе, и в новых социально-экономических условиях эффективной оказалась торговля, предпринимательская деятельность, эта ниша оказалась незанятой. Предпринимательство на благо общины признано средством спасения веры и души. В общественном плане задача уже не спасение веры, а её «возрастание» ${ }^{2}$. Строгий семейный уклад, отказ от расточительства, от мирских удовольствий, патрональное отношение к общине способствовали созданию больших семейных состояний купцов-старообрядцев. В России ко времени Николая I более 50\% частного капитала в торговле и промышленности принадлежало старообрядцам ${ }^{3}$. Их тип хозяйствования строился на конфессиональном единстве, доверии, системе взаимопомощи и кредита.

Старообрядчество в XX-XXI вв. изменилось в связи с переходом от аграрно-традиционного к индустриальному обществу, урбанизацией, революционными потрясениями и т.д. Согласно данным Ю.Ю. Синелиной, старообрядцами себя считают $5 \%$ россиян ${ }^{4}$. Среди причин возвращения старообрядчества в политическую культуру нашей страны цивилизационные, социокультурные и общественно-политические:

1. цивилизационный кризис, связанный с трансформацией системообразующих ценностей социума активизирует поиск национальной идеи. Из ретроспективных религиозных концептов староверие выступает бескомпромиссной идеей русскости, традиционности, осознания уникальности в истории, импульса развития России на самобытных экономических и социально-политических основаниях и стратегиях;

2. старообрядчество сохранило уникальные культурные формы: книжности, иконы, музыки, бытового уклада, семьи. Обращение к старообрядчеству - это обращение к истокам русской культуры. Старообрядчество воплощает «русскую идею» и русский мессианизм в истории;

3. старообрядчество не отождествлялось с государством и характеризовалось нестяжа-

\footnotetext{
${ }^{1}$ Островский А.Б. Старообрядцы и православные в русском сельском социуме. Вторая половина XIX-XX век: Формы общения. Ритуальная специфика: Этнографические очерки. СПб., 2011. С. 273.

${ }^{2}$ КеровВ.В. Старообрядчество: от общего суда к спасению личной души. Старообрядчество: история, культура, современность: Тезисы III научно-практич. конф. М., Музей истории и культуры старообрядчества, 1997. С. 60.

${ }_{3}$ Расков Д.Е. Старообрядческое предпринимательство: попытки теоретического осмысления. Старообрядчество. История, культура, современность. 1998. С. 86.

${ }^{4}$ Синелина Ю.Ю. Насколько православны наши православные. Журнал Московской патриархии. 2012 , №8, С. 78.
} Научно-аналитический вестник ИЕ РАН, 2019, №3 
тельством и широким внутренним демократизмом. В силу исторических обстоятельств в общине существует распределение обязанностей между верующими. Основным лицом административно-хозяйственной жизни староверской общины выступает староста и общинный совет, в их функции не вмешивается священник. Такой стиль жизни гарантировал выживание. Изучение вероучения и уклада древлеправославия способствуют развитию институтов гражданского общества, так как у России есть свои демократические традиции: «Христианская религия в тех случаях, когда она не обслуживает интересы государства, сама по себе крепкая основа для развития демократического строя» ${ }^{1},-$ говорит сотрудник центра древнерусской духовной культуры «Старая Русь» Д. Лупекин. Россия имеет традиции демократического устроения, связанные со старообрядческой соборностью как формой консервативной демократии. Старообрядчество - пример автономной самоорганизации без помощи и контроля государства, западных влияний в сторону формирования свободного общества с традиционными ценностями. Оно культивирует солидарность, ценность духовной жизни, истории.

Современные старообрядцы становятся более открытыми обществу, несмотря на исторически сложившееся противопоставление всему остальному миру в прошлом, так как оно: «изначально имело и религиозную и социальную значимость, определяя границы общины... В конце XX - начале XXI в. оно по-прежнему значимо для исторической памяти общины и её актуальной идентичности» ${ }^{2}$. Перед старообрядцами стоит задача сохранения идентичности в секулярном и многоконфессиональном пространстве с развитием конфессии через катехизацию и ознакомление не старообрядцев со своей культурой. Их «мирским призванием» сегодня становится социальное служение, понимаемое как миссия сохранения старообрядческих общин и культуры старообрядчества, приобщение к её богатствам молодёжи и всех интересующихся идеями «русского мира». На это направлены усилия руководства старообрядческих согласий, часть их материальных ресурсов. Социальная активность старообрядческого сообщества фиксируется в материалах соборов РПСЦ, РДЦ, старообрядческой прессе и полевых исследованиях.

Статистика Минюста не даёт точного количества старообрядческих общин в РФ, т.к. они не стремятся к обязательной регистрации, не имеющей отношения к исповеданию веры. Но наблюдатели отмечают: «Растёт, хоть и медленно, число старообрядческих общин. Так, в Коврове была зарегистрирована община РПСЦ, настоятель которой будет служить в недавно переданном властями старообрядческой Церкви доме. Надо выделить и поставление клириков к храмам РПСЦ в Сызрани и Балаково. Эти места освящены старообрядческим прошлым: там был легендарный Иргиз. В июне был совершён чин освящения храма в селе Безводное Нижегородской области, в августе - в г. Лысьве Уральской епархии, затем - в с. Селиваниха Орехово-Зуевского района Московской епархии. Московская митрополия РПСЦ постепенно отходит от политики контактов и встреч с иноверцами, переходя к решению первостепенных внутренних задач: кадровой, интеллектуальной и социальной» ${ }^{3}$.

Полевые исследования среди старообрядцев Нижегородской области (РПСЦ, РДЦ, поморцев) свидетельствуют о развитой приходской общинной жизни у старообрядцев. Многие участвуют в службе семьями. Жизнь в храме не заканчивается богослужением, прихожане учатся знаменному распеву, изучают старопечатные книги, плетут лестовки и многое другое.

\footnotetext{
${ }_{1}^{1}$ Русские демократические традиции. Старообрядец, №43, 2008. С. 1-2.

2 Островский А.Б. Старообрядцы и православные в русском сельском социуме. Вторая половина XIX-XX век: Формы общения. Ритуальная специфика: Этнографические очерки. СПб., 2011. С. 272.

${ }^{3}$ Иволгин Виктор для «Портала-Credo.Ru». Взгляд со стороны: Лицом к интеллигенции. В уходящем году российские старообрядцы спорили, строили и смотрели кино. Самарское старообрядчество. URL: http://samstar. ucoz.ru/news/vzgljad so storony licom_k intelligencii_v ukhodjashhem godu_rossijskie staroobrjadcy sporili_stroil i_i_smotreli_kino/2011-12-29-5172 (дата обращения: 22.06.2013).
}

Научно-аналитический вестник ИЕ РАН, 2019, №3 
Обычно для старообрядцев ношение традиционного русского костюма во время богослужений, особенно праздничных. Молодёжь охотно участвует в реставрационных работах, социальном служении. Постоянно о необходимости работы с молодёжью как дела всей церкви и формах этой работы говорит в соборных выступлениях митрополит Корнилий. В Московской Митрополии РПСЦ действует отдел по работе с молодёжью, возглавляемый иереем Александром Масловым. В активе отдела успешно проведённые мероприятия: паломнические поездки и походы, молодёжные встречи, конференции. Такая деятельность нужна в епархиях, в приходах, подчёркивает митрополит Корнилий, ибо: «Надо стремиться к тому, чтобы наша церковная молодёжь увидела и нашла своё место в Церкви» ${ }^{1}$. РПСЦ расширяет экскурсионную деятельность среди студентов и школьников в восстанавливаемой Рогожской слободе, где они узнают о традициях староверия. Более того: «в правительство Москвы нами были внесены предложения по расширению и улучшению работы Церкви с молодёжью: создание центра ремесел, центра народного творчества, репетиционной базы для певческих коллективов; создание паломнического центра, постоялого двора для паломников; учреждение медицинского центра для инвалидов и больных; организация приюта для сирот и бездомных; рассмотрение возможности выделения эфирного времени для демонстрации фильмов и выпуска телепередач с религиозной тематикой» ${ }^{2}$. Подобное предложение можно рассматривать как преодоление изоляционизма и переход к миссии в молодёжной среде.

Силами московского правительства возродился Рогожский архитектурно-исторический ансамбль. Подчёркивается необходимость выработки концепции развития Рогожского комплекса в культурной и паломнической среде столицы. Среди общероссийских проектов реставрации старообрядческих центров можно назвать проект Древлеправославной Поморской Церкви по рекультивации Русского Севера. В Нарьян-Маре закончено в 2014 г. на средства и при участии предпринимателя поморца Вальтера Вальтеровича Фото строительство паломнического комплекса на месте заключения и гибели протопопа Аввакума ${ }^{3}$. В г. Нижнем Новгороде установлены памятники известным старообрядческим благотворителям и меценатам, внёсшим весомый вклад в развитие города - Н.А. Бугрову и Д. В. Сироткину. В Нижегородской области ведутся работы по сохранению святых могилок и скитов, установлено более двадцати пяти памятных крестов на месте разорения старообрядческих монастырей, мест самосожжений, иноческого подвига старообрядческих святых.

Изучение истории и культуры старообрядчества: «может сплотить русский народ и способствовать его духовно-нравственному возрождению» ${ }^{4}$, поэтому старообрядческие согласия переходят к открытой информационной политике. С 2004 г. действует созданный по благословению митрополита Андриана официальный сайт РПСЦ. В Интернете работает ряд ресурсов: Русской Древлеправославной Церкви, Древлеправославной Поморской Церкви, рассказывающих о жизни, новостях, истории и традициях старообрядчества. Как отмечал митрополит Корнилий: «Если в прошлом о старообрядчестве чаще писали и говорили люди внешние, то сегодня доступна информация, можно сказать, из первых рук» ${ }^{5}$. Смысл информационной

\footnotetext{
${ }^{1}$ Доклад митрополита Московского и всея Руси Корнилия Освящённому Собору РПСЦ, 16.10.2008. Самарское старообрядчество. ULR: http://samstar.ucoz.ru/news/2008-10-16-1174- (дата обращения: 21.06.2017).

2 Доклад митрополита Корнилия Освящённому Собору Русской Православной Старообрядческой Церкви 2010 г. Часть 1. Самарское старообрядчество. URL: http://samstar.ucoz.ru/news/doklad_mitropolita_kornilija_osvjashhenno mu soboru russkoj_pravoslavnoj_staroobrjadcheskoj_cerkvi 2010_g/2010-10-22-4140 (дата обращения: 22.06.2017).

${ }_{4}^{3}$ Иволгин Виктор для «Портала-Credo.Ru». Там же (дата обращения: 22.06.2017).

4 Доклад митрополита Московского и всея Руси Корнилия Освящённому Собору РПСЦ. Москва, 20.10.2009. Самарское старообрядчество. URL: http://samstar.ucoz.ru/news/doklad mitropolita moskovskogo_i vseja rusi kor nilija_osvjashhennomu_soboru_russkoj_pravoslavnoj_staroobrjadcheskoj_cerkvi/2009-10-20-2755 (дата обращения: 21.06.2017).

${ }^{5}$ Там же.
} 
политики изучение истории старообрядчества и миссия в интернет пространстве.

В 2011 г. староверы с удовлетворением встретили фильм режиссёра Н. Досталя «Раскол», где консультантом был сотрудник Московской митрополии РПСЦ Глеб Чистяков. Создано эпическое полотно о событиях прошлого. На прошедших с середины 1990-х гг. конференциях «Старообрядчество: история, культура, современность» выступило более 630 учёных из разных стран мира, а по итогам конференций было подготовлено и издано 8 сборников материалов.

В 2012 г. старообрядчество отметило исторические памятные даты - 330-летие казни пустозерских мучеников и исповедников протопопа Аввакума, иерея Лазаря, дьякона Феодора и инока Епифания. Проведены вечера песнопений, совершён крестный ход на родину протопопа Аввакума в с. Григорово из Большого Мурашкина в Нижегородской области. Состоялся круглый стол «Книжные богатства Русской Православной Старообрядческой Церкви и доступ к ним: Цели, задачи, проблемы, перспективы», организованный архивно-библиотечным отделом Митрополии в рамках проекта «Общедоступный читальный зал Архива и Библиотеки редких книг и рукописей Русской Православной Старообрядческой Церкви». В Нижегородском государственном художественном музее проходят Вечера Духовных песнопений, в которых принимают участие хоровые коллективы из Нижнего Новгорода (хор Успенской общины и Никольской общины г. Арзамас) и Санкт-Петербурга (хор Свято-Троицкого храма Лиговской общины).

Большое значение в развитии старообрядческой культуры имеет написание семейных, локальных историй старообрядчества, где фиксируется ценный краеведческий материал и изустные семейные предания. Примером такого рода литературы является иллюстрированная книга «Поморцы Керженского Заволжья» ${ }^{1}$, написанная по инициативе и финансовой поддержке нижегородского предпринимателя Павла Григорьевича Лебедева.

Первоочередной задачей старообрядческого сообщества является развитие духовного образования. Существует практика самообразования, поэтому остро стоит проблема теологической и церковной грамотности. Как свидетельствует митрополит Корнилий: «Наша Церковь нуждается в образованных священнослужителях, головщиках, уставщиках, преподавателях воскресных школ. Духовное образование сегодня одна из основных задач нашей Церкви» ${ }^{2}$. Вопрос духовного образования актуален для всех согласий, он основа духовного просвещения в приходе, работы воскресных школ, экскурсионно-паломнической деятельности среди детей и подростков. Старообрядцы обеспокоены духовно-нравственным состоянием молодёжи под влиянием массовой псевдокультуры, потери нравственных ориентиров «свободы выбора между добром и злом», привлекая к этому общественное внимание. Необходима опора на общественное согласие, возвращение к истокам и формам устроения духовной жизни, дававшим возможность народу Руси преодолевать любые трудности: «всё, что касается инициатив государства и других традиционных конфессий по сохранению духовности, здоровья нации мы поддерживаем и участвуем в этом, если это не противоречит устоям и правилам нашей веры» ${ }^{3}$. У старообрядчества появилась ещё одна возможность донести свой голос до всех, кто хочет услышать их мнение о путях преодоления духовного, культурного и экономического кризиса: «Выступление на подобных форумах показывает, что старообрядчество, со-

\footnotetext{
1 Лебедев П., Голубева Н. Поморцы Керженского Заволжья. Бор, 2011.

2 Доклад митрополита Московского и всея Руси Корнилия Освящённому Собору Русской Православной Старообрядческой Церкви. Москва, 20.10.2009. Самарское старообрядчество. URL: http://samstar.ucoz.ru/news/doklad mitropolita moskovskogo i_vseja rusi_kornilija osvjashhennomu_soboru russkoj pravoslavnoj_staroobrjadcheskoj cerkvi/2009-10-20-2755 (дата обращения: 21.06.2017).

${ }^{3}$ Доклад митрополита Корнилия ... 2010 г. Ч. І. См. упомянутое (дата обращения: 22.06.2013).
} Научно-аналитический вестник ИЕ РАН, 2019, №3 
хранившее веру своих предков, живо и готово участвовать в меру своих сил в духовном возрождении России» ${ }^{1}$.

Таким образом, в определении своего место в российской политической культуре, государственно-конфессиональных отношениях и социальном служении современное старообрядчество ориентируется на исторический опыт, личную аскезу и необходимость вершить добрые дела и демонстрировать личный христианский пример в секулярном мире. Идёт сложный и небыстрый процесс восстановления старообрядческих общин. Старообрядческая культура - это синтез русского варианта византийского православия и народной культуры, уходящей корнями в дохристианскую Русь. Она формируется в переходный период ухода православной древнерусской культуры и зарождения рационалистической антропоцентрической секуляризованной культуры, поэтому в мировоззрении старообрядцев отражаются особенности уходящей и нарождающейся культур. Старообрядчество - проявление становления русского национального самосознания, осознание духовного своеобразия русского народа и его культуры; его сторонники выступают защитниками самобытных духовных начал и остаются их живыми носителями и хранителями. Эволюция старообрядчества показывает возможности адаптации традиционной духовной культуры к современности, наличие в ней значительного творческого потенциала, ярко проявившегося в XIX - начале XX в. и вызывающем всё больший интерес сегодня. Примером такой адаптации русской культуры и религиозного традиционализма с демократической политической культурой может быть жизнь больших (Литва, Латвия, Румыния) и малых (Польша, Болгария) общин старообрядцев в европейских странах, а так же на Украине и в Беларуси.

В местах своего проживания за рубежом старообрядцы не практиковали активной миссионерской деятельности среди местного населения. Однако вступление в брак со старообрядцем требовало перекрещивания, что приводило в общины этнических русских старообрядцев иностранцев. Кроме этого, нельзя отрицать личного духовного искания отдельных людей и их принятие старообрядческого направления христианства. Так в 2003 г. в епископы Русской Православной Старообрядческой Церкви (РПСЦ) был рукоположен немец - Михаэль Герцог (ныне епископ Амвросий). Он был и католиком, и протестантом, и православным. В интервью «НГР» епископ рассказал о причинах, побудивших его принять старую русскую веру: «Священное Писание, которое является фундаментом протестантизма, - важная, но не единственная основа нашей веры. Христианину также необходимо иметь руководство к пониманию Библии, что невозможно без древней церковной традиции, опирающейся на Священное Предание. Если мы соглашаемся с тем, что Писание и Предание составляют основу Церкви, то нужно задаться вопросом, кто и по каким причинам Предание изменил, а кто сохранил его в неизменности. Я пришёл к выводу, что в самой чистой и ясной форме оно сохранено в Русской Православной Старообрядческой Церкви» ${ }^{2}$. Еп. Амвросий окормляет два старообрядческих прихода в Германии, самый большой в г. Аугсбурге. Туда ходят и этнические русские и иностранцы. Богослужения ведутся на старославянском, так же переводятся на немецкий, чтобы быть понятными заходящим в храм немцам. Для Германии это, своего рода, экзотика, но существующая на легальных основаниях европейской демократической политической культуры, признающей незыблемость принципов свободы совести.

\footnotetext{
${ }^{1}$ Там же.

${ }^{2}$ Как немцу стать старообрядцем. НГ-религии, 03.03.2004. URL: http://www.ng.ru/ng religii/2004-03-03/8 amvro si.html (дата обращения: 28.06.2019).
}

Научно-аналитический вестник ИЕ РАН, 2019, №3 


\section{Список литературы}

Доклад митрополита Московского и всея Руси Корнилия Освящённому Собору Русской Православной Старообрядческой Церкви. Москва, 20.10.2009. Самарское старообрядчество. URL: http://samstar.ucoz.ru/news/doklad_mitropolita_moskovskogo_i_vseja_rusi_kornilija_osvjas hhennomu_soboru_russkoj_pravoslavnoj_staroobrjadcheskoj_cerkvi/2009-10-20-2755 (дата обращения: 21.06.2017).

Доклад митрополита Московского и всея Руси Корнилия Освящённому Собору РПСЦ, 16.10.2008. Самарское старообрядчество. URL: http://samstar.ucoz.ru/news/2008-10-16-1174 (дата обращения: 21.06.2017).

Доклад митрополита Корнилия Освящённому Собору Русской Православной Старообрядческой Церкви 2010 г. Часть 1. Самарское старообрядчество. URL: http://samstar.ucoz.ru/news/ doklad_mitropolita_kornilija_osvjashhennomu_soboru_russkoj_pravoslavnoj_staroobrjadcheskoj_c erkvi_2010_g/2010-10-22-4140 (дата обращения: 22.06.2017).

Иволгин Виктор для «Портала-Credo.Ru». Взгляд со стороны: Лицом к интеллигенции. В уходящем году российские старообрядцы спорили, строили и смотрели кино. Самарское старообрядчество. URL: http://samstar.ucoz.ru/news/vzgljad_so_storony_licom_k_intelligencii_v_uk hodjashhem_godu_rossijskie_staroobrjadcy_sporili_stroili_i_smotreli_kino/2011-12-29-5172 (дата обращения: 22.06.2017).

Как немцу стать старообрядцем. НГ-религии, 03.03.2004. ULR: http://www.ng.ru/ng_religii/ 2004-03-03/8_amvrosi.html (дата обращения: 28.06.2019).

Керов В.В. Старообрядчество: от общего суда к спасению личной души. Старообрядчество: история, культура, современность: Тезисы III научно-практич. конф. М.: Музей истории и культуры старообрядчества, 1997. С. 60.

Лебедев П., Голубева Н. Поморцы Керженского Заволжья. Бор, 2011.

Островский А.Б. Старообрядцы и православные в русском сельском социуме. Вторая половина XIX-XX век: Формы общения. Ритуальная специфика: Этнографические очерки. СПб., 2011. С. 272.

Расков Д.Е. Старообрядческое предпринимательство: попытки теоретического осмысления. Старообрядчество. История, культура, современность. 1998. С. 86.

Русские демократические традиции. Старообрядец, №43, 2008. С. 1-2.

Синелина Ю.Ю. Насколько православны наши православные. Журнал Московской патриархии, №8, 2012. С. 78.

Смирнов М.Ю. Религия и религиоведение в России. СПб., 2013, С. 27.

\section{References}

Doklad mitropolita Moskovskogo i vseya Rusi Korniliya Osvyashchennomu Soboru Russkoj Pravoslavnoj Staroobryadcheskoj Cerkvi. Moskva, 20.10.2009 g Samarskoe staroobryadchestvo. URL: http://samstar.ucoz.ru/news/doklad_mitropolita_moskovskogo_i_vseja_rusi_kornilija_osvjas hhennomu_soboru_russkoj_pravoslavnoj_staroobrjadcheskoj_cerkvi/2009-10-20-2755 (data obrashcheniya: 21.06.2017).

Doklad mitropolita Moskovskogo i vseya Rusi Korniliya Osvyashchennomu Soboru RPSC, 16.10.2008. Samarskoe staroobryadchestvo. URL: http://samstar.ucoz.ru/news/2008-10-16-1174(data obrashcheniya: 21.06.2017)/

Doklad mitropolita Korniliya Osvyashchennomu Soboru Russkoj Pravoslavnoj Staroobryadcheskoj Cerkvi 2010 g. Chast' 1. Samarskoe staroobryadchestvo. URL: http://samstar.ucoz.ru/news/ 
doklad_mitropolita_kornilija_osvjashhennomu_soboru_russkoj_pravoslavnoj_staroobrjadcheskoj_c erkvi_2010_g/2010-10-22-4140 (data obrashcheniya: 22.06.2017).

Ivolgin Viktor dlya «Portala-Credo.Ru». Vzglyad so storony: Licom k intelligencii. V uhodyashchem godu rossijskie staroobryadcy sporili, stroili i smotreli kino. Samarskoe staroobryadchestvo. URL: http://samstar.ucoz.ru/news/vzgljad_so_storony_licom_k_intelligencii_v_ukhodjashhem_go du_rossijskie_staroobrjadcy_sporili_stroili_i_smotreli_kino/2011-12-29-5172 (data obrashcheniya: 22.06.2017).

Kak nemcu stat' staroobryadcem. NG-religii, 03.03.2004. URL: http://www.ng.ru/ng_religii/ 2004-03-03/8_amvrosi.html (data obrashcheniya: 28.06.2019).

Kerov V.V. Staroobryadchestvo: ot obshchego suda k spaseniyu lichnoj dushi. Staroobryadchestvo: istoriya, kul'tura, sovremennost': Tezisy III nauchno-praktich. konf. M.: Muzej istorii i kul'tury staroobryadchestva, 1997. S. 60.

Lebedev P., Golubeva N. Pomorcy Kerzhenskogo Zavolzh’ya. Bor, 2011.

Ostrovskij A.B. Staroobryadcy i pravoslavnye v russkom sel'skom sociume. Vtoraya polovina HIH-HKH vek: Formy obshcheniya. Ritual'naya specifika: EHtnograficheskie ocherki. SPb., 2011. S. 272.

Raskov D.E. Staroobryadcheskoe predprinimatel'stvo: popytki teoreticheskogo osmysleniya. Staroobryadchestvo. Istoriya, kul'tura, sovremennost'. 1998. S. 86.

Russkie demokraticheskie tradicii. Staroobryadec, №43, 2008. S. 1-2.

Sinelina Yu.Yu. Naskol'ko pravoslavny nashi pravoslavnye. ZHurnal Moskovskoj patriarhii. №8, 2012. S. 78.

Smirnov M.Yu. Religiya i religiovedenie v Rossii. SPb., 2013. S. 27.

\section{Old Believers in Modern Political Culture: European Values}

Authors. Olga Shimanskaya, Candidate of Sciences (Philosophy), Associate Professor, Senior Researcher, Institute of Europe, Russian Academy of Sciences. Address: 11-3, Mokhovaya str., Moscow, Russia, 125009. E-mail: shimansk@mail.ru.

Annotation. The article discusses how to adapt the Old Believers in the modern Russian political culture based on the analysis of official Old Believer documents, materials of the confessional press, as well as the author's field research. Conclusions are drawn about the reasons for the return of the Old Believers in the socio-political discourse of modern state-confessional relations, forecasts are made regarding the influence of the Old Believers on modern Russian political culture in the direction of its democratization.

Keywords: Old Believers, Russian world, traditionalism, identity, politics, culture.

DOI: http://dx.doi.org/10.15211/vestnikieran32019117124 